\title{
Prajinamide, a new modified peptide from a soil-derived Streptomyces
}

\author{
Yasuhiro Igarashi $^{1}$, Yuki Tanaka ${ }^{1}$, Megumi Ikeda ${ }^{2}$, Tsutomu Oikawa ${ }^{2}$, Shigeru Kitani ${ }^{3}$, Takuya Nihira ${ }^{3,4}$, \\ Phayungsak Mongkol $^{4}$, Mayura Janhom ${ }^{4}$ and Watanalai Panbangred ${ }^{4,5}$
}

The Journal of Antibiotics (2012) 65, 157-159; doi:10.1038/ja.2011.132; published online 22 February 2012

Keywords: adipocyte differentiation; peptide; Streptomyces

Actinomycetes are well recognized as the richest source of bioactive compounds, including clinically important antibiotics, antitumor agents and cell function modulators, and hence of high pharmacological and commercial interest. ${ }^{1}$ Amongst this group, members of the genus Streptomyces are the most prolific producers of secondary metabolites, accounting for up to $80 \%$ of the bioactive small molecules discovered from actinomycetes. ${ }^{2}$ Meanwhile, it is quite notable that further discovery of unknown metabolites from Streptomyces is predicted by the genome analysis: the number of metabolites actually isolated is far more below the number of secondary metabolite biosynthetic gene clusters identified in the whole genomes of $S$. avermitilis and $S$. coelicolor. ${ }^{3,4}$ As a part of our chemical investigation on microbial secondary metabolites, we reported plant-growth promoting spiroacetals of polyketide origin, ${ }^{5}$ a linear polyketide with a $\delta$ lactone terminus with cytotoxic activity, ${ }^{6}$ a polycyclic tetronate with antiinvasive activity $^{7}$ and a biosynthetically unprecedented heterocyclic polyketide with antibacterial and antiinvasive activities ${ }^{8}$ from Streptomyces. During the course of our continuing effort to discover structurally unique secondary metabolites from these organisms, a new modified peptide was isolated from the culture broth of a soilderived actinomycete strain Streptomyces sp. SPMA113 collected in Thailand. The strain was cultured in A-11M liquid medium, and the whole culture broth was extracted with 1-butanol. The HPLC/UV analysis of the extract using our in-house metabolite database indicated the presence of an unknown compound showing a UV absorption maximum at $260 \mathrm{~nm}$, along with geldanamycins ${ }^{9}$ and elaiophylins. ${ }^{10}$ Guided by HPLC/UV, several steps of chromatographic purification resulted in the isolation of a new compound, prajinamide (1, Figure 1).

Compound 1 was obtained as a pale yellow oil that analyzed for a molecular formula of $\mathrm{C}_{16} \mathrm{H}_{25} \mathrm{~N}_{3} \mathrm{O}_{3}$ (6 degrees of unsaturation) by interpretation of HR-ESI-TOF-MS (observed $[\mathrm{M}+\mathrm{Na}]^{+}$at $\mathrm{m} / \mathrm{z}$ 330.1788, calculated $[\mathrm{M}+\mathrm{Na}]^{+}$330.1788). This molecular formula was corroborated by ${ }^{1} \mathrm{H}$ and ${ }^{13} \mathrm{C}$ NMR spectral data (Table 1). Analysis of the combined $1 \mathrm{D}$ and $2 \mathrm{D}$ NMR data established that 1 possessed three carbonyl, four olefinic methine, two $\mathrm{sp}^{3}$ methine, five $\mathrm{sp}^{3}$ methylene and two methyl carbons, in addition to three exchangeable protons. The IR absorptions at 1647,1599 and $1538 \mathrm{~cm}^{-1}$ indicated the presence of amide functionalities, which was supported by the resonances of carbonyl carbons at $\delta$ 165.6, 169.9 and 170.1 observed in the ${ }^{13} \mathrm{C}$ NMR spectrum. As three carbonyls and two double bonds accounted for five of six double-bond equivalents, 1 must be a monocyclic compound.

Further analysis of ${ }^{1} \mathrm{H}-{ }^{1} \mathrm{H}$ COSY and $\mathrm{HMBC}$ spectra provided three substructures (Figure 2). The first was an ornithine lactam that was established by the sequential COSY correlations from an $\mathrm{NH}$ proton at $\delta 7.61(2-\mathrm{NH})$ to another $\mathrm{NH}$ proton at $\delta 8.07(5-\mathrm{NH})$ through a methine proton $(\mathrm{H}-2)$ and three methylene protons $(\mathrm{H}-3, \mathrm{H}-4$ and $\mathrm{H}-5)$ and HMBC correlations from H-2, H-3, H-5 and 2-NH to a carbonyl carbon $\mathrm{C}-1$ ( $\delta$ 169.9). The second substructure, a $\beta$-alanine, was assigned on the basis of COSY correlations between an $\mathrm{NH}$ proton at $\delta 7.98(8-\mathrm{NH})$ and $\mathrm{H}-8$ and between $\mathrm{H}-8$ and $\mathrm{H}-7$ and HMBC correlations from $\mathrm{H}-7$ and $\mathrm{H}-8$ to $\mathrm{C}-6$ ( $\delta$ 170.1). Two and three-bond $\mathrm{C}-\mathrm{H}$ correlations from $2-\mathrm{NH}$ and $\mathrm{H}-2$ to $\mathrm{C}-6$ allowed the $\beta$-alanine residue being connected to the ornithine lactam through an amide linkage. COSY correlations between four olefinic protons $\mathrm{H}-10, \mathrm{H}-11$, $\mathrm{H}-12$ and $\mathrm{H}-13$ provided a conjugated diene, which was then extended to include a carbonyl carbon C-9 $(\delta$ 165.6) at C-10 on the basis of HMBC correlations from $\mathrm{H}-10$ and $\mathrm{H}-11$ to $\mathrm{C}-9$. A vinyl methine $\mathrm{H}-13$ showed a COSY correlation to $\mathrm{H}-14$, which showed in turn correlations to two equivalent methyl protons $\mathrm{H}-15$ and $\mathrm{H}-16$, thereby establishing an isopropyl terminus attached to the diene fragment. The geometries of C-10-C-11 and C-12-C-13 double bonds were assigned as $Z$ and $E$, respectively, on the basis of the vicinal coupling constants $\left(J_{\mathrm{H} 10, \mathrm{H} 11}=11.3 \mathrm{~Hz}, J_{\mathrm{H} 12, \mathrm{H} 13}=15.5 \mathrm{~Hz}\right)$. The third substructure was thus

\footnotetext{
${ }^{1}$ Biotechnology Research Center, Toyama Prefectural University, Toyama, Japan; ${ }^{2}$ School of Nutrition and Dietetics, Kanagawa University of Human Services, Kanagawa, Japan; ${ }^{3}$ International Center for Biotechnology, Osaka University, Osaka, Japan; ${ }^{4}$ Mahidol University and Osaka University Collaborative Research Center on Bioscience and Biotechnology, Bangkok, Thailand and ${ }^{5}$ Department of Biotechnology, Faculty of Science, Mahidol University, Bankok, Thailand

Correspondence: Professor Y Igarashi, Biotechnology Research Center, Toyama Prefectural University, 5180 Kurokawa, Imizu, Toyama 939-0398, Japan.

E-mail: yas@pu-toyama.ac.jp

Received 12 November 2011; revised 5 December 2011; accepted 7 December 2011; published online 22 February 2012
} 
<smiles>CC(C)/C=C/C=C/C(=O)NCCC(=O)N[C@H]1CCCNC1=O</smiles>

prajinamide (1)

Figure 1 Structure of prajinamide (1).

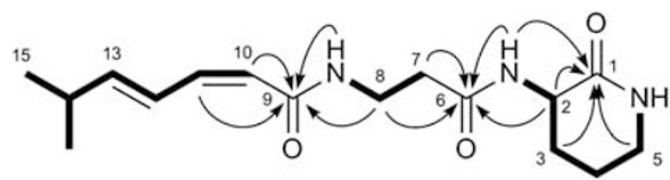

$\longrightarrow{ }^{1} \mathrm{H}^{-1} \mathrm{HCOSY} \rightleftharpoons \mathrm{HMBC}$

Figure $2{ }^{1} \mathrm{H}^{1}{ }^{1} \mathrm{H}$ COSY and key HMBC correlations for 1 .

Table $1{ }^{1} \mathrm{H}$ and ${ }^{13} \mathrm{C}$ NMR data for prajinamide (1) in DMSO- $d_{6}$

\begin{tabular}{|c|c|c|c|}
\hline Position & $\delta_{C}{ }^{a}$ & $\delta_{H}$ mult $(\mathrm{J} \text { in } \mathrm{Hz})^{\mathrm{b}}$ & $H M B C^{b, c}$ \\
\hline 1 & 169.9, qC & & \\
\hline 2 & $48.8, \mathrm{CH}$ & 4.14, ddd $(10.7,8.3,6.0)$ & 1,6 \\
\hline \multirow[t]{2}{*}{3} & $27.6, \mathrm{CH}_{2}$ & 1.58, dddd $(12.5,11.0,10.7,4.0)$ & $1,2,5$ \\
\hline & & $1.92, \mathrm{~m}$ & $1,2,5$ \\
\hline \multirow[t]{2}{*}{4} & $21.0, \mathrm{CH}_{2}$ & $1.71, \mathrm{~m}$ & \\
\hline & & $1.75, \mathrm{~m}$ & 2,5 \\
\hline 5 & $40.9, \mathrm{CH}_{2}$ & $3.11, \mathrm{~m}$ & 1 \\
\hline 6 & 170.1, qC & & \\
\hline \multirow[t]{2}{*}{7} & $35.3, \mathrm{CH}_{2}$ & 2.25, ddd $(17.0,6.8,6.8)$ & 6,8 \\
\hline & & 2.27, ddd $(17.0,6.8,6.8)$ & 6,8 \\
\hline \multirow[t]{2}{*}{8} & $35.1, \mathrm{CH}_{2}$ & 3.27, dddd $(19.3,6.8,6.8,6.3)$ & $6,7,9$ \\
\hline & & 3.31, dddd $(19.3,6.8,6.8,6.3)$ & $6,7,9$ \\
\hline 9 & 165.6, qC & & \\
\hline 10 & 119.7, $\mathrm{CH}$ & $5.59, \mathrm{~d}(11.3)$ & 9,12 \\
\hline 11 & $140.1, \mathrm{CH}$ & 6.32, dd $(11.3,11.0)$ & 9,13 \\
\hline 12 & $124.3, \mathrm{CH}$ & 7.45, dd $(15.5,11.0)$ & 11,14 \\
\hline 13 & $148.5, \mathrm{CH}$ & 5.91, dd $(15.5,6.7)$ & $11,14,15,16$ \\
\hline 14 & $30.7, \mathrm{CH}$ & 2.37, dqq $(6.7,6.3,6.3)$ & $12,13,15,16$ \\
\hline 15 & $21.8, \mathrm{CH}_{3}$ & $0.98, d(6.3)$ & $13,14,16$ \\
\hline 16 & $21.8, \mathrm{CH}_{3}$ & $0.98, d(6.3)$ & $13,14,15$ \\
\hline 2-NH & & $8.07, d(8.3)$ & $1,2,6$ \\
\hline $5-\mathrm{NH}$ & & $7.61, \mathrm{~s}$ & \\
\hline 8-NH & & $7.98, t(6.3)$ & $7,8,9$ \\
\hline
\end{tabular}

aRecorded at $100 \mathrm{MHz}$.

becorded at $500 \mathrm{MHz}$

cHMBC correlations are from proton(s) stated to the indicated carbon.

established as 6-methyl-(2Z, 4E)-hepta-2,4-dienoate. This unit was connected to the $\beta$-alanine residue via an amide bond on the basis of HMBC correlations from 8-NH and $\mathrm{H}-8$ to C-9, providing the planar structure of $\mathbf{1}$ as depicted in Figure 2. The absolute configuration of the ornithine lactam residue in $\mathbf{1}$ was determined to have the L configuration by Marfey's analysis. ${ }^{11}$ The acid hydrolysate of 1 was derivatized with L-FDLA (1-fluoro-2,4-dinitrophenyl-5-L-leucinamide), and the HPLC retention time was compared with D- and L-ornithine standards that were similarly derivatized with L-FDLA. The derivatized D- and L-ornithine standards eluted at 9.8 and $13.4 \mathrm{~min}$, respectively, while the L-FDLA derivative of the acid hydrolysate of 1 eluted at $13.5 \mathrm{~min}$.

The biological activity of prajinamide (1) is still being examined in diverse bioassays. To date, $\mathbf{1}$ was found to induce differentiation of preadipocytes into matured adipocytes. Adipocytes have ability to secrete adiponectin, a peptidic hormone that is beneficial to improve insulin-sensitivity in insulin-resistant type 2 diabetes patients. ${ }^{12}$ Small molecules that induce adipocyte differentiation are thus expected as leads for antidiabetic agents. ${ }^{13}$ By the treatment with $50 \mu \mathrm{M}$ prajinamide, $60 \%$ of murine ST- 13 preadipocyte cells were differentiated into matured adipocytes with accumulation of cytosolic lipid droplets. Further detailed analysis of its inducing activity as well as the induction of adiponectin secretion is under investigation. Compound 1 was inactive in a cancer cell cytotoxicity assay $\left(\mathrm{IC}_{50}>100 \mu \mathrm{M}\right.$ against MCF7 human breast cancer cells) and an antimicrobial assay against Escherichia coli, Micrococcus luteus and Candida albicans $\left(\mathrm{MIC}>50 \mu \mathrm{g} \mathrm{ml}^{-1}\right)$.

Prajimamide (1) is a relatively simple compound consisting of three small building blocks, but no similar metabolites are known with respect to its overall structure. Specifically, the unsaturated fatty acid unit, 6-methyl-(2Z, 4E)-hepta-2,4-dienoate, is unprecedented in natural products, whereas its $2 E$ isomer has been found only in daryamide C from Streptomyces. ${ }^{14}$ The discovery of $\mathbf{1}$ is the result of our comprehensive chemical screening from Streptomyces, providing additional evidence that this species is still a promising source of structurally novel small molecules.

\section{EXPERIMENTAL PROCEDURE}

\section{General experimental procedures}

Optical rotation was measured using a JASCO DIP-3000 polarimeter (JASCO Corporation, Tokyo, Japan). UV spectrum was recorded on a Hitachi U-3210 spectrophotometer (Hitachi, Tokyo, Japan). IR spectrum was measured on a Perkin Elmer Spectrum 100 (Perkin-Elmer, Fremont, CA, USA). NMR spectra were obtained on a Bruker AVANCE 400 or a Bruker AVANCE 500 spectrometer (Bruker, Rheinstetten, Germany) in DMSO- $d_{6}$, referenced to residual solvent signals ( $\delta 2.49$ for ${ }^{1} \mathrm{H} ; \delta 39.5$ for ${ }^{13} \mathrm{C}$ ). HR-ESI-TOF-MS was recorded on a Bruker microTOF focus. Silica Gel 75-C18 (Nacalai Tesque, Kyoto, Japan, $75 \mu \mathrm{M})$ was used for ODS column chromatography.

\section{Microorganism}

Strain SPMA113 was isolated from a soil sample collected in Prajinburi Province, Thailand. The strain was identified as a member of the genus Streptomyces on the basis of $98.9 \%$ similarity of $16 \mathrm{~S}$ rRNA gene sequence (1393 nucleotides; GenBank accession number HQ340163) to the nearest type strain Streptomyces malaysiensis ATB- $11^{\mathrm{T}}$ (accession number AF117304).

\section{Fermentation}

Strain SPMA113 cultured on a Bn-2 slant (soluble starch $0.5 \%$, glucose $0.5 \%$, meat extract (Kyokuto Pharmaceutical Industrial, Tokyo, Japan) 0.1\%, yeast extract (Difco Laboratories, Becton, Dickinson and Company, Sparks, MD, USA) $0.1 \%$, NZ-case (Wako Chemicals USA, Richmond, VA, USA) $0.2 \%, \mathrm{NaCl} 0.2 \%, \mathrm{CaCO}_{3}$ $0.1 \%$, agar $1.5 \%$ ) was inoculated into $500 \mathrm{ml} \mathrm{K-1}$ flasks (K-Techno, Toyama, Japan) each containing $100 \mathrm{ml}$ of the $\mathrm{V}-22$ seed medium consisting of soluble starch $1 \%$, glucose $0.5 \%$, NZ-case $0.3 \%$, yeast extract $0.2 \%$, tryptone (Difco Laboratories) $0.5 \%, \mathrm{~K}_{2} \mathrm{HPO}_{4} 0.1 \%, \mathrm{MgSO}_{4} \cdot 7 \mathrm{H}_{2} \mathrm{O} 0.05 \%$ and $\mathrm{CaCO}_{3} 0.3 \%$ (pH 7.0). The flasks were placed on a rotary shaker ( 200 r.p.m.) at $30^{\circ} \mathrm{C}$ for 4 days. The seed culture ( $3 \mathrm{ml}$ ) was transferred into $500 \mathrm{ml} \mathrm{K-1}$ flasks each containing $100 \mathrm{ml}$ of the A-11M production medium consisting of glucose $0.2 \%$, soluble starch $2.5 \%$, polypeptone $\mathrm{N}$ (Wako Chemicals USA) $0.5 \%$, yeast extract $0.5 \%$, NZ-amine (Wako Chemicals USA) $0.5 \%, \mathrm{CaCO}_{3} 0.3 \%$ and Diaion HP-20 (Mitsubishi Chemical, Tokyo, Japan) $1 \%$. The $\mathrm{pH}$ of the medium was adjusted to 7.0 before sterilization. The inoculated flasks were placed on a rotary shaker $(200$ r.p.m. $)$ at $30^{\circ} \mathrm{C}$ for 6 days.

\section{Extraction and isolation}

At the end of the fermentation period, $50 \mathrm{ml}$ of 1-butanol were added to each flask, and they were allowed to shake for $1 \mathrm{~h}$. The mixture was centrifuged at 5000 r.p.m. for $10 \mathrm{~min}$, and the organic layer was separated from the aqueous 
layer containing the mycelium. Evaporation of the solvent gave $2.9 \mathrm{~g}$ of extract from 21 of culture. The crude extract $(2.9 \mathrm{~g})$ was subjected to silica gel column chromatography with a step gradient of $\mathrm{CHCl}_{3} / \mathrm{MeOH}(1: 0,20: 1,10: 1,4: 1$, $2: 1,1: 1$ and $0: 1 \mathrm{v} / \mathrm{v})$. Fraction 5 was concentrated to provide $0.57 \mathrm{~g}$ of brown oil, which was further purified by reversed phase ODS column chromatography with a gradient of $\mathrm{MeCN} / 0.1 \% \mathrm{HCO}_{2} \mathrm{H}(2: 8,3: 7,4: 6,5: 5,6: 4,7: 3$ and $8: 2 \mathrm{v} / \mathrm{v})$. Fraction 3 was evaporated and the remaining aqueous solution was extracted with EtOAc. The aqueous layer was then lyophilized to give a yellow powder $(7.1 \mathrm{mg})$. Final purification was achieved by preparative C-18 HPLC using a Cosmosil 5C18-AR-II column (Nacalai Tesque, $10 \times 250 \mathrm{~mm}$ ) with $\mathrm{MeCN} / 0.1 \% \mathrm{HCO}_{2} \mathrm{H}(30: 70$ for $0-5 \mathrm{~min}, 30: 70$ to $40: 60$ over $5-25 \mathrm{~min}$ ) at $3 \mathrm{ml} \mathrm{min}{ }^{-1}$, followed by evaporation and lyophilization, yielding prajinamide $(1,4.2 \mathrm{mg})$ with a retention time of $12.2 \mathrm{~min}$.

Prajinamide (1): pale yellow oil; $[\alpha]_{\mathrm{D}}^{24}-3.0(c 0.15, \mathrm{MeOH})$; UV $(\mathrm{MeOH})$ $\lambda_{\max }(\log \varepsilon) 260 \mathrm{~nm}$ (3.80); IR (ATR) $v_{\max } 3267,1647,1599,1538 \mathrm{~cm}^{-1} ;{ }^{1} \mathrm{H}$ and ${ }^{13} \mathrm{C}$ NMR data, see Table 1; HR-ESI-TOF-MS $[\mathrm{M}+\mathrm{Na}]^{+} 330.1788$ (calculated for $\mathrm{C}_{16} \mathrm{H}_{25} \mathrm{~N}_{3} \mathrm{O}_{3} \mathrm{Na} 330.1788$ ).

\section{Marfey's analysis}

A portion of $1(0.1 \mathrm{mg})$ was hydrolyzed at $110^{\circ} \mathrm{C}$ with $6 \mathrm{M} \mathrm{HCl}(200 \mu \mathrm{l})$ for $6 \mathrm{~h}$, and the reaction mixture was evaporated to dryness. A $0.1 \mathrm{M} \mathrm{NaHCO}_{3}$ solution $(100 \mu \mathrm{l})$ was added to the dried hydrolysate of $\mathbf{1}$, as well as to standards of $\mathrm{L}-$ and D-ornithine (Orn). A solution of 1-fluoro-2,4-dinitrophenyl-5-L-leucinamide ( $\mathrm{L}-\mathrm{FDLA})$ in acetone $(0.05 \mathrm{mg}$ in $50 \mu \mathrm{l})$ was added to each reaction tube. Each tube was sealed and incubated at $50^{\circ} \mathrm{C}$ for $30 \mathrm{~min}$. To quench reactions, $2 \mathrm{M} \mathrm{HCl}(50 \mu \mathrm{l})$ was added and then diluted with $\mathrm{MeCN} / 0.2 \% \mathrm{HCO}_{2} \mathrm{H}(100 \mu \mathrm{l}$, 50 : 50). The Marfey's derivatives of the hydrolysate and standards were analyzed by HPLC using a Cosmosil 5C18-AR-II column (Nacalai Tesque, $4.6 \times 250 \mathrm{~mm}$ ) eluted with $\mathrm{MeCN}-2 \% \mathrm{HCO}_{2} \mathrm{H}$ at a flow rate of $1.0 \mathrm{ml} \mathrm{min}^{-1}$, monitoring at $340 \mathrm{~nm}$. The gradient elution was set as follows: $0-5 \mathrm{~min}(25 \%$ $\mathrm{MeCN})$, 5-45 min (25-55\% MeCN). Retention times for the amino acid standards were $13.4 \mathrm{~min}$ for L-Orn-L-FDLA and $9.8 \mathrm{~min}$ for D-Orn-L-FDLA, while the L-FDLA-hydrolysate of 1 gave a peak at $13.5 \mathrm{~min}$.

\section{Biological assays}

Adipocyte differentiation assay, ${ }^{13}$ antimicrobial assay ${ }^{7}$ and cytotoxic assay ${ }^{15}$ were carried out according to the procedures previously described. Rosiglitazone, ${ }^{16}$ an antidiabetic drug, was used as a positive control in the adipocyte differentiation assay. It induced differentiation in $80 \%$ of murine ST- 13 preadipocyte cells at $0.02 \mu \mathrm{m}$.

\section{ACKNOWLEDGEMENTS}

We acknowledge Dr T Okuda and Ms Y Sudoh at Tamagawa University for assistance with antimicrobial assay. This research was supported in part by the joint program in the field of biotechnology under the Japan Society for the Promotion of Science (JSPS) and the National Research Council of Thailand (NRCT).

1 Butler, M. S. Natural products to drugs: natural product-derived compounds in clinical trials. Nat. Prod. Rep. 25, 475-516 (2008).

2 Bérdy, J. Bioactive microbial metabolites. J. Antibiot. 58, 1-26 (2005).

3 Omura, S. et al. Genome sequence of an industrial microorganism Streptomycesavermitilis: deducing the ability of producing secondary metabolites. Proc. Natl Acad. Sci. USA 98, 12215-12220 (2001).

4 Bentley, S. D. et al. Complete genome analysis of the model actinomycete Streptomyces coelicolor A3(2). Nature 417, 141-147 (2002).

5 Igarashi, Y., Iida, T., Yoshida, R. \& Furumai, T. Pteridic acids A and B, novel plant growth promoters with auxin-like activity from Streptomyces hygroscopicus TP-A0451. J. Antibiot. 55, 764-767 (2002).

6 Igarashi, Y., Miura, S., Fujita, T. \& Furumai, T. Pterocidin, a cytotoxic compound from the endophytic Streptomyces hygroscopicus. J. Antibiot. 59, 193-195 (2006).

7 Igarashi, Y. et al. Abyssomicin I, a modified polycyclic polyketide from Streptomyces sp. CHI39. J. Nat. Prod. 73, 1943-1946 (2010)

8 Igarashi, Y. et al. Alchivemycin A, a bioactive polycyclic polyketide with an unprecedented skeleton from Streptomyces sp. Org. Lett. 12, 3402-3405 (2010).

9 Sasaki, K., Rinehart, K. L., Slomp, G., Grostic, M. F. \& Olson, E. C. Geldanamycin. I. Structure assignment. J. Am. Chem. Soc. 92, 7591-7593 (1970).

10 Kaiser, H. \& Keller-Schierlein, W. Stoffwechselprodukte von Mikroorganismen. 202. Mitteilung. Strukturauklärung von Elaiophylin: Spektroskopische Untersuchungen und Abbau. Helv. Chim. Acta. 64, 407-424 (1981).

11 Bhushan, R. \& Bruckner, H. Marfey's reagent for chiral amino acid analysis: a review. Amino Acids 27, 231-247 (2004).

12 Kadowaki, T. et al. Adiponectin and adiponectin receptors in insulin resistance, diabetes, and the metabolic syndrome. J. Clin. Invest. 116, 1784-1792 (2006).

13 Kunimasa, K. et al. Identification of nobiletin, a polymethoxyflavonoid, as an enhancer of adiponectin secretion. Bioorg. Med. Chem. Lett. 19, 2062-2064 (2009).

14 Asolkar, R. N., Jensen, P. R., Kaufmann, C. A. \& Fenical, W. Daryamides A-C, weakly cytotoxic polyketides from a marine-derived actinomycete of the genus Streptomyces strain CNQ-085. J. Nat. Prod. 69, 1756-1759 (2006).

15 Fukuda, T. et al. Marianins A and B, prenylated phenylpropanoids from Mariannaea camptospora. J. Nat. Prod. 74, 1327-1330 (2011).

16 Diamant, M. \& Heine, R. J. Thiazolidinediones in type 2 diabetes mellitus: current clinical evidence. Drugs 63, 1373-1405 (2003). 